Review

\title{
Alkaloids from the Tribe Bocconieae (Papaveraceae): A Chemical and Biological Review
}

\author{
Xuelong Yu ${ }^{1,2, \dagger}$, Xiaoli Gao ${ }^{1, \dagger}$, Zhixiang Zhu ${ }^{1}$, Yuan Cao ${ }^{1,2}$, Qian Zhang ${ }^{1}$, Pengfei Tu ${ }^{1, *}$ and \\ Xingyun Chai ${ }^{1, *}$
}

1 Modern Research Center for Traditional Chinese Medicine, Beijing University of Chinese Medicine, Beijing 100029, China

2 School of Chinese Materia Medica, Beijing University of Chinese Medicine, Beijing 100102, China

$\dagger$ These authors contributed equally to the work.

* Authors to whom correspondence should be addressed; E-Mails: pengfeitu@vip.163.com (P.T.); xingyunchai@yeah.net (X.C.); Tel./Fax: +86-10-8280-2750 (P.T.); +86-10-6428-6350 (X.C.).

Received: 14 May 2014; in revised form: 12 August 2014; / Accepted: 20 August 2014 /

Published: 25 August 2014

\begin{abstract}
The Bocconieae tribe, consisting of only the genera Macleaya and Bocconia, possesses significant economic and medicinal value and plays an important role in health management for people in developing countries. During the past decades, research on metabolites and relative pharmacology, including the isolation and identification of a variety of molecules, has shed light on the tribe. Among those molecules, isoquinoline alkaloids, and their antimicrobial, antifungal, and anti-inflammatory activities are especially noteworthy. This paper presents a comprehensive compilation of current research progress, with emphasis on the alkaloids and their distribution, phytochemical and pharmacological investigation, toxicity and side effects, related chemotaxonomy and future use prospects, and hopefully provides a valuable reference as an effort to promote further exploration and application of this tribe.
\end{abstract}

Keywords: Papaveraceae; Macleaya; Bocconia; alkaloids; bioactivity; review 


\section{Introduction}

The Papaveraceous plants are very well-known for their extensive economic use as well as medicinal ones, which are directly associated with their rich production of alkaloids with novel structures and significant bioactivities. A variety of alkaloids, such as morphine, codeine, protopine, isocorydine, and tetrahydropalmatine, were discovered in this family, and they have irreplaceable therapeutic value in the treatment of many diseases.

The Bocconieae is a small tribe consisting of only two closely related genera, Macleaya and Bocconia, which share similarities in morphology and chemical components. The genus Macleaya contains two slightly toxic species, M. cordata (Willd.) R. Br. and M. microcarpa (Maxim.) Fedde, distributed in East Asia and widely found in South and Northwest China [1]. The genus Bocconia, on the other hand, includes $c a$. nine species, distributed mainly in tropical areas of Mexico, Central and Southern America [2].

The plants of the tribe Bocconieae play an important role as sources of traditional medicines for people in developing countries. For example, B. frutescens is used in Mexico to treat skin ulcers, dermatitis, and some respiratory tract infections, as well as tuberculosis [3]. B. arborea is employed for the treatment of diverse infectious diseases and is variously known in Mexico as llora sangre (weeping blood), cocoxíhuitl, ahuacachilli, mano de león (lion's hand), palo del diablo (devil's stick), palo amarillo (yellow stick). Native residents also use $B$. arborea as a purgative, vermifuge, antitumor, and anti-inflammatory agent to heal wounds and dissolve warts, or as a carminative agent to take advantage of its cathartic and analgesic activities [2,4]. M. cordata has been widely used as folk medicine in China, North America, and Europe, where it has been applied to cure cervical cancer and thyroid cancer, according to clinical records [5].

Modern chemistry and pharmacology research has revealed that alkaloids are the characteristic ingredients, overwhelming in quantity, and account for the major bioactivities of most Papaveraceous plants [6]. Therefore, this paper compiles complete data of alkaloids from the plants of the tribe Bocconieae, focusing on their distribution, isolation, structural features, and pharmacological activities, and hopefully may provide a useful reference for further studies on this tribe.

\section{Chemical Constituents}

A total of 75 alkaloids have been described from Bocconieae species so far, including the predominant benzophenanthridines (BPAs) 1-50, protoberberines 51-64, protopines 65-69 and other types 70-75. Their structures are displayed in Figures 1 and 2, and their names, corresponding source plants, parts, and references are listed in Tables 1 and 2.

The BPA type of alkaloids, derived from protoberberines via $\mathrm{N}-\mathrm{C}_{6}$ bond cleavage and the formation of $C_{6}-C_{13}$ bonds is one of the characteristic and chemotaxonomic components in the plants of the family Papaveraceae [7,8]. The BPAs in the plants of the tribe Bocconieae cover dihydrobenzophen-anthridines (1-20, 32-36, 39-42), quaternary BPAs (QBPAs, 21-24, 29-31), $N$-demethylated BPAs 25-28, hexahydrobenzophenanthridines 37-38, dimeric BPAs 44-50, and the seco-BPA 43. Among them, some (compounds 4, 9, 10, 17, 18, 21, 29, 48, 49, 66, and 67) are widespread, especially $\mathbf{2 1}, \mathbf{2 9}$, and 65-67, and some (compounds $4,8-10,16$, and 30) are less abundant, 
while 51, 53 and 54 are scarce in this tribe. Dimers 44-50 from B. arborea and M. microcarpa are considered artifacts probably derived from reactions occuring during the extraction and isolation, although the possibility their natural existence cannot be completely excluded, as similar dimers were also described in plants of the genus Dactylicapnos in the same family [9]. Compound 7 should not be a natural product, as it is obviously derived from the use of $n$-butanol during its extraction. Furthermore, compounds 56, 58, 59, and 70-73 are obtained in cell cultures of M. cordata.

Figure 1. Structures of compounds 1-50 from the tribe Bocconieae.<smiles></smiles>

$1 \mathrm{R}_{1}=\beta \mathrm{OMe}, \mathrm{R}_{2}=\mathrm{H}$

$2 \mathrm{R}_{1}=\mathrm{OMe}, \mathrm{R}_{2}=\mathrm{H}$

$3 \mathrm{R}_{1}=\mathrm{H}, \mathrm{R}_{2}=\mathrm{OMe}$

$4 \mathrm{R}_{1}=\mathrm{R}_{2}=\mathrm{H} ; 5 \quad \mathrm{R}_{1}=\mathrm{R}_{2}=\mathrm{OMe}$

$6 \mathrm{R}_{1}=\alpha \mathrm{OH}, \mathrm{R}_{2}=\mathrm{H}$

$7 \mathrm{R}_{1}=\mathrm{OC}_{4} \mathrm{H}_{9}, \mathrm{R}_{2}=\mathrm{H}$

$8 \mathrm{R}_{1}=\mathrm{O}, \mathrm{R}_{2}=\mathrm{H}$<smiles>[R2]c1cc2c(c3c1-c1ccc4cc5c(cc4c1N(C)C3[R1])OCO5)OCO2</smiles>

$9 \mathrm{R}_{1}==\mathrm{O}, \mathrm{R}_{2}=\mathrm{H}$ $10 \mathrm{R}_{1}=\mathrm{R}_{2}=\mathrm{H}$

$11 \mathrm{R}_{1}=\mathrm{H}, \mathrm{R}_{2}=\mathrm{OMe}$

$12 \mathrm{R}_{1}=\mathrm{OMe}, \mathrm{R}_{2}=\mathrm{H}$

$13 \mathrm{R}_{1}=\alpha \mathrm{OMe}, \mathrm{R}_{2}=\mathrm{H}$

$14 \mathrm{R}_{1}=\mathrm{OMe}, \mathrm{R}_{2}=\mathrm{OMe}$ $15 \mathrm{R}_{1}=\mathrm{OEt}, \mathrm{R}_{2}=\mathrm{H}$<smiles>[R]C[C@H]1c2c(ccc([R6])c2O[R20])-c2ccc3cc4c(cc3c2N1C)OCO4</smiles>

$16 \mathrm{R}_{1}=\mathrm{OH}, \mathrm{R}_{2}=\mathrm{R}_{3}=\mathrm{Me}$

$17 \mathrm{R}_{1}=\mathrm{COMe}, \mathrm{R}_{2}=\mathrm{R}_{3}=\mathrm{Me}$

$18 \mathrm{R}_{1}=\mathrm{COMe}, \mathrm{R}_{2}+\mathrm{R}_{3}=\mathrm{CH}_{2}$

$19 \mathrm{R}_{1}=\mathrm{COOH}, \mathrm{R}_{2}+\mathrm{R}_{3}=\mathrm{CH}_{2}$

$20 \mathrm{R}_{1}=\mathrm{COOH}, \mathrm{R}_{2}=\mathrm{R}_{3}=\mathrm{Me}$<smiles></smiles>

$\begin{array}{lll}\mathrm{R}_{1} & \mathrm{R}_{2} & \mathrm{R}_{3}\end{array}$

$21 \mathrm{Me} \mathrm{H} \quad \mathrm{H}$

$22 \mathrm{Me} \mathrm{OMe} \mathrm{H}$

$23 \mathrm{H} \quad \mathrm{H} \quad \mathrm{H}$

$24 \mathrm{Me} \mathrm{H}$ OEt

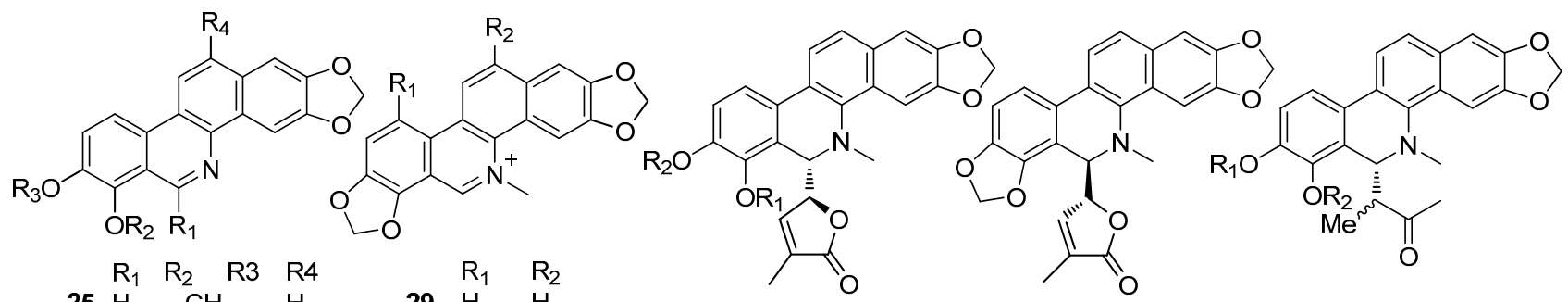

$\begin{array}{llllllll} & \mathrm{R}_{1} & \mathrm{R}_{2} & \mathrm{R} 3 & \mathrm{R} 4 & & \mathrm{R}_{1} & \mathrm{R}_{2} \\ \mathbf{2 5} & \mathrm{H} & \mathrm{CH}_{2} & \mathrm{H} & \mathbf{2 9} & \mathrm{H} & \mathrm{H} \\ \mathbf{2 6} & \mathrm{H} & \mathrm{CH}_{2} & \mathrm{OMe} & \mathbf{3 0} & \mathrm{OMe} & \mathrm{H} \\ \mathbf{2 7} & \mathrm{OMe} & \mathrm{CH}_{2} & \mathrm{H} & \mathbf{3 1} & \text { OMe } & \mathrm{OMe} \\ \mathbf{2 8} & \mathrm{H} & \mathrm{Me} & \mathrm{Me} & \mathrm{H} & & & \end{array}$

$32 \mathrm{R}_{1}=\mathrm{R}_{2}=\mathrm{Me}$

$33 \mathrm{R}_{1}+\mathrm{R}_{2}=\mathrm{CH}_{2}$
34

$35 \mathrm{R}_{1}=\mathrm{R}_{2}=\mathrm{Me}$ $36 \mathrm{R}_{1}+\mathrm{R}_{2}=\mathrm{CH}_{2}$<smiles>[R]Oc1c([R20])ccc2c1CN(C)C1c3cc4c(cc3C[C@H](O)[C@@H]21)OCO4</smiles>
$38 \mathrm{R}_{1}+\mathrm{R}_{2}=\mathrm{CH}_{2}$ $\mathrm{OH} \mathrm{OH}$

40 $426 R, 1^{\prime} R$

43<smiles>COc1cc2c(cc1OC)[C@@](C)(C(=O)C[C@H]1c3c(ccc(OC)c3OC)-c3ccc4cc5c(cc4c3N1C)OCO5)N(C)c1c-2ccc2cc3c(cc12)OCO3</smiles><smiles></smiles>

45<smiles></smiles>

$46 \beta ; 47 \alpha$<smiles>[R20]c1ccc2c(c1OC)[C@H]1CC(=O)C[C@@H](C)[C@](C)(c3ccc4cc5c(cc4c3N1C)OCO5)c1c-2ccc(OC)c1OC</smiles>

$48 \mathrm{R}_{1}+\mathrm{R}_{2}=\mathrm{CH}_{2}, \alpha$;

$49 \mathrm{R}_{1}+\mathrm{R}_{2}=\mathrm{CH}_{2}, \beta ; 50 \quad \mathrm{R}_{1}=\mathrm{R}_{2}=\mathrm{Me}, \alpha$ 
Figure 2. Structures of compounds 51-75 from Bocconieae.

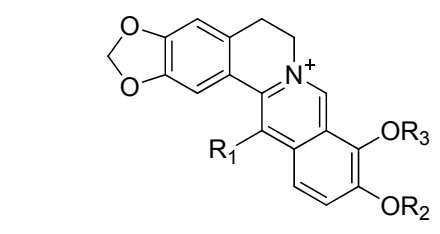

$$
\begin{aligned}
& 51 \mathrm{R}_{1}=\mathrm{H}, \mathrm{R}_{2}=\mathrm{R}_{3}=\mathrm{Me} \\
& 52 \mathrm{R}_{1}=\mathrm{R}_{3}=\mathrm{H}, \mathrm{R}_{2}=\mathrm{Me} \\
& 53 \mathrm{R}_{1}=\mathrm{H}, \mathrm{R}_{2}+\mathrm{R}_{3}=\mathrm{CH}_{2} \\
& 54 \mathrm{R}_{1}=\mathrm{Me}, \mathrm{R}_{2}+\mathrm{R}_{3}=\mathrm{CH}_{2}
\end{aligned}
$$

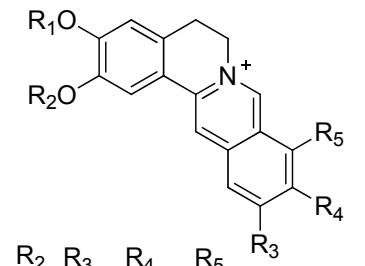<smiles>[R2]c1cc2c(c([R])c1OC)CN1CCc3cc(OC)c(OC)cc3C1C2</smiles><smiles>[R]Oc1ccc2c(c1OC)CN1CCc3cc(OC)c(O)cc3[C@H]2C1</smiles>

$58 \mathrm{R}_{1}=\mathrm{OH}, \mathrm{R}_{2}=\mathrm{H}$ $59 \mathrm{R}_{1}=\mathrm{H}, \mathrm{R}_{2}=\mathrm{OH}$

$60 \mathrm{R}=\mathrm{Me}$ $61 \mathrm{R}=\mathrm{H}$<smiles></smiles><smiles>[R20]Oc1cc2c(cc1O[R20])C(=O)Cc1ccc3c(c1CN(C)CC2)OCO3</smiles>
$67 \mathrm{R}_{1}+\mathrm{R}_{2}=\mathrm{CH}_{2}$

64

$65 \beta ; 66 \alpha$ $68 \mathrm{R}_{1}=\mathrm{R}_{2}=\mathrm{Me}$

69

62Me; $63 \alpha \mathrm{Me}$

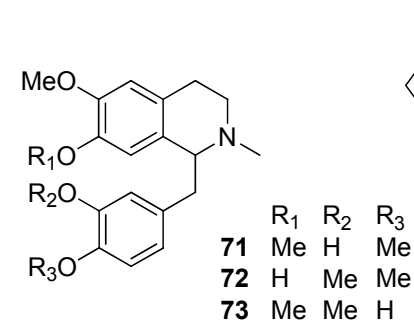

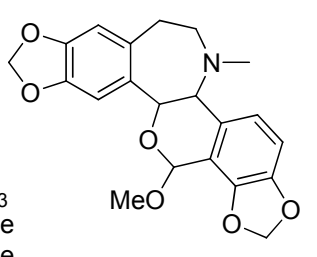

74<smiles>O=C(/C=C/c1ccc(O)cc1)NCCc1ccc(O)cc1</smiles>

75

In addition to the major BPA alkaloids, other types of constituents, including phenolic acids, essential oil (2-methoxy-4-vinylphenol) [10,11], polysaccharides, flavonoids, steroids [12] from M. cordata, and a triterpene ( $3 \alpha$-hydroxyolean-12-en-30-oic acid) from B. arborea [13] were also reported.

\begin{tabular}{|c|c|c|c|c|c|}
\hline & Name & Type & Plant & Part & Ref. \\
\hline 1 & 11-O-Methyldihydrochelerythrine & $\mathrm{I}_{\mathrm{A}}$ & B. arborea & - & [16] \\
\hline 2 & $\begin{array}{l}\text { Angoline }(( \pm) \text {-6-methoxydihydro- } \\
\text { chelerythrine })\end{array}$ & $\mathrm{I}_{\mathrm{A}}$ & $\begin{array}{c}\text { M. cordata } \\
\text { B. arborea } \\
\text { M. microcarpa }\end{array}$ & $\begin{array}{c}\text { Stems } \\
\text { Leaves, stems } \\
\text { Aerial parts, roots }\end{array}$ & $\begin{array}{c}{[17]} \\
{[2]} \\
{[14,18,19]}\end{array}$ \\
\hline 3 & 12-Methoxydihydrochelerythrine & $\mathrm{I}_{\mathrm{A}}$ & B. integrifolia & Leaves & {$[20]$} \\
\hline 4 & Dihydrochelerythrine & $\mathrm{I}_{\mathrm{A}}$ & $\begin{array}{l}\text { B. integrifolia } \\
\text { B. arborea } \\
\text { B. frutescens } \\
\text { M. microcarpa } \\
\text { M. cordata } \\
\text { B. pearcei }\end{array}$ & $\begin{array}{c}\text { Leaves } \\
\text { Aerial parts } \\
\text { Leaves } \\
\text { Roots, leaves, whole plant } \\
\text { Fruits } \\
\text { Fruits }\end{array}$ & $\begin{array}{c}{[20]} \\
{[4]} \\
{[3]} \\
{[14,21,22]} \\
{[23]} \\
{[24]}\end{array}$ \\
\hline
\end{tabular}

Besides distribution and structural features, determination of stereochemistry of the alkaloids is another important issue, not only for the structural elucidation, but also for the clarification of reaction mechanism(s), especially for those alkaloids with complex skeletons and more than one chiral center. The relative configurations of compounds 17 and 32-34 were solved by X-ray single-crystal diffraction and analysis of circular dichroism data [14,15]. However, the absolute configurations of many of these alkaloids remaining unresolved, and in need of further research efforts.

Table 1. Alkaloids isolated from Bocconieae. 
Table 1. Cont.

\begin{tabular}{|c|c|c|c|c|c|}
\hline & Name & Type & Plant & Part & Ref. \\
\hline 5 & 6, 12-Dimethoxydihydrocheleritrine & $\mathrm{I}_{\mathrm{A}}$ & B. arborea & - & [25] \\
\hline 6 & 8-Hydroxydihydrochelerythrine & $\mathrm{I}_{\mathrm{A}}$ & M. cordata. & Seeds & [26] \\
\hline 7 & 6-Butoxydihydrochelerythrine & $\mathrm{I}_{\mathrm{A}}$ & M. microcarpa & Roots & [14] \\
\hline 8 & Oxychelerythrine & $\mathrm{I}_{\mathrm{A}}$ & B. pearcei & Fruits & [24] \\
\hline \multirow{4}{*}{9} & \multirow{4}{*}{ Oxysanguinarine } & \multirow{4}{*}{$\mathrm{I}_{\mathrm{A}}$} & B. latisepala & Leaves, roots, seeds & [27] \\
\hline & & & B. arborea & - & [16] \\
\hline & & & B. pearcei & Fruits & [24] \\
\hline & & & M. cordata & - & [10] \\
\hline \multirow{5}{*}{10} & \multirow{5}{*}{ Dihydrosanguinarine } & \multirow{5}{*}{$\mathrm{I}_{\mathrm{A}}$} & M. cordata & Fruits & [23] \\
\hline & & & B. integrifolia & Leaves & [20] \\
\hline & & & B. arborea & Aerial parts & {$[4,16]$} \\
\hline & & & M. microcarpa & Roots, leaves, whole plant & {$[14,21,22]$} \\
\hline & & & B. Pearcei & Fruits & {$[24]$} \\
\hline \multirow{2}{*}{11} & \multirow{2}{*}{ Dihydrochelirubine } & \multirow{2}{*}{$\mathrm{I}_{\mathrm{A}}$} & B. integrifolia & Leaves & [20] \\
\hline & & & B. pearcei & Fruits & [24] \\
\hline \multirow{2}{*}{12} & \multirow{2}{*}{ 6-Methoxydihydrosanguinarine } & \multirow{2}{*}{$\mathrm{I}_{\mathrm{A}}$} & M. cordata & Fruits & [10] \\
\hline & & & M. microcarpa & Roots & [14] \\
\hline 13 & 8-Methoxydihydrosanguinarine & $\mathrm{I}_{\mathrm{A}}$ & M. cordata & Seeds & [26] \\
\hline 14 & 6-Methoxydihydrochelirubine & $\mathrm{I}_{\mathrm{A}}$ & B. arborea & - & [25] \\
\hline \multirow{2}{*}{15} & \multirow{2}{*}{ 6-Ethoxysanguinarine } & \multirow{2}{*}{$\mathrm{I}_{\mathrm{A}}$} & M. cordata & - & [10] \\
\hline & & & M. microcarpa & Whole plant & [21] \\
\hline \multirow{2}{*}{16} & \multirow{2}{*}{ Bocconoline } & \multirow{2}{*}{$\mathrm{I}_{\mathrm{A}}$} & B. cordata & - & [28] \\
\hline & & & M. cordata & - & [10] \\
\hline \multirow{3}{*}{17} & \multirow{3}{*}{$( \pm$ )-6-Acetonyldihydrochelerythrine } & \multirow{3}{*}{$\mathrm{I}_{\mathrm{A}}$} & B. arborea & Barks, aerial parts & {$[2,15]$} \\
\hline & & & B. frutescens & Leaves & {$[3]$} \\
\hline & & & M. cordata & Fruits & {$[10,23]$} \\
\hline \multirow{4}{*}{18} & \multirow{4}{*}{$( \pm)$-6-Acetonyldihydrosanguinarine } & \multirow{4}{*}{$\mathrm{I}_{\mathrm{A}}$} & B. arborea & Aerial parts & [2] \\
\hline & & & B. frutescens & Leaves & [3] \\
\hline & & & M. cordata & Fruits & {$[10,23]$} \\
\hline & & & M. microcarpa & Whole plant & {$[21]$} \\
\hline \multirow{2}{*}{19} & Spallidamine & & M. microcarpa & Roots & [14] \\
\hline & (6-Carboxymethyldihydrosanguinarie) & $1_{A}$ & M. cordata & Whole plant & [12] \\
\hline 20 & 6-Carboxymethyldihydrochelerythrine & $\mathrm{I}_{\mathrm{A}}$ & M. cordata & Whole plant & [12] \\
\hline & & & B. latisepala & Barks, stems, seeds & [27] \\
\hline 21 & Chelervthrine & $\mathrm{J}_{\mathrm{g}}$ & M. cordata & - & [29] \\
\hline 21 & Cnelerytnrine & $\mathrm{I}_{\mathrm{B}}$ & B. frutescens & Roots, stalks and leaves & [30] \\
\hline & & & M. microcarpa & - & [31] \\
\hline 22 & Chelilutine & & M. cordata & Roots & {$[10]$} \\
\hline & Chellutine & $\mathrm{I}_{\mathrm{B}}$ & M. microcarpa & - & [31] \\
\hline 23 & 8-O-Demethylchelerythrine & $\mathrm{I}_{\mathrm{B}}$ & M. cordata & - & [29] \\
\hline 24 & 6-Ethoxychelerythrine & $\mathrm{I}_{\mathrm{B}}$ & M. cordata & - & [10] \\
\hline 25 & Norsanguinarine & $\mathrm{I}_{\mathrm{C}}$ & M. cordata & Fruits & {$[10]$} \\
\hline
\end{tabular}


Table 1. Cont.

\begin{tabular}{|c|c|c|c|c|c|}
\hline & Name & Type & Plant & Part & Ref. \\
\hline 26 & 12-Methoxynorchelerythrine & $\mathrm{I}_{\mathrm{C}}$ & B. pearcei & Fruits & [24] \\
\hline 27 & Pancorine & $\mathrm{I}_{\mathrm{C}}$ & M. microcarpa & Roots & [14] \\
\hline 28 & Norchelerythrine & $\mathrm{I}_{\mathrm{C}}$ & M. cordata & Whole plant & [12] \\
\hline \multirow{5}{*}{29} & \multirow{5}{*}{ Sanguinarine } & \multirow{5}{*}{$\mathrm{I}_{\mathrm{B}}$} & B. latisepala & Barks, stems & [27] \\
\hline & & & B. cordata & Leaves & [32] \\
\hline & & & B. frutescens & Roots, stalks and leaves & [30] \\
\hline & & & M. cordata. & Fruits & {$[29,33]$} \\
\hline & & & M. microcarpa & Aerial parts & {$[18,19,34]$} \\
\hline \multirow{2}{*}{30} & \multirow{2}{*}{ Bocconine (chelirubine) } & \multirow{2}{*}{$\mathrm{I}_{\mathrm{B}}$} & B. cordata & - & {$[35]$} \\
\hline & & & M. microcarpa & - & [31] \\
\hline \multirow{2}{*}{31} & \multirow{2}{*}{ Macarpine } & \multirow{2}{*}{$\mathrm{I}_{\mathrm{B}}$} & M. cordata & Callus tissues & {$[10,36]$} \\
\hline & & & M. microcarpa & - & {$[31]$} \\
\hline 32 & Maclekarpine A & $\mathrm{I}_{\mathrm{A}}$ & M. microcarpa & Roots & [14] \\
\hline 33 & Maclekarpine B & $\mathrm{I}_{\mathrm{A}}$ & M. microcarpa & Roots & [14] \\
\hline 34 & Maclekarpine C & $\mathrm{I}_{\mathrm{A}}$ & M. microcarpa & Roots & [14] \\
\hline 35 & $6 \alpha$-Isobutanonyldihydrochelerythrine & $\mathrm{I}_{\mathrm{A}}$ & M. cordata & Fruits & [23] \\
\hline 36 & $6 \alpha$-Isobutanonyldihydrosanguinarine & $\mathrm{I}_{\mathrm{A}}$ & M. cordata & Fruits & [23] \\
\hline 37 & Homochelidonine & $\mathrm{I}_{\mathrm{D}}$ & M. cordata & - & [10] \\
\hline 38 & Chelidonine & $\mathrm{I}_{\mathrm{D}}$ & B. frutescens & Roots & [37] \\
\hline 39 & Maclekarpine D & $\mathrm{I}_{\mathrm{A}}$ & M. microcarpa & Roots & [14] \\
\hline 40 & Maclekarpine E & $\mathrm{I}_{\mathrm{A}}$ & M. microcarpa & Roots & [14] \\
\hline 41 & 6-(1'-hydroxyethyl)-dihydrochelerythrine & $\mathrm{I}_{\mathrm{A}}$ & M. microcarpa & Roots & [14] \\
\hline 42 & $\begin{array}{c}R-6-((R)-1-\text { Hydroxyethyl)- } \\
\text { dihydrochelerythrie }\end{array}$ & $\mathrm{I}_{\mathrm{A}}$ & M. cordata & Whole plant & [12] \\
\hline 43 & Arnottianamide & $I_{F}$ & M. microcarpa & Roots & [14] \\
\hline 44 & Chelerythridimerine & $\mathrm{I}_{\mathrm{E}}$ & B. arborea & Barks & [38] \\
\hline 45 & Bis[6-(5, 6-dihydrochelerythrinyl)]ether & $I_{E}$ & M. microcarpa & Roots & [14] \\
\hline \multirow{2}{*}{46} & \multirow{2}{*}{$( \pm)$-Sanguidimerine } & \multirow{2}{*}{$\mathrm{I}_{\mathrm{E}}$} & B. arborea & Aerial parts & [2] \\
\hline & & & M. cordata & Leaves & [10] \\
\hline \multirow{2}{*}{47} & \multirow{2}{*}{ Chelidimerine } & \multirow{2}{*}{$\mathrm{I}_{\mathrm{E}}$} & B. arborea & Aerial parts & [2] \\
\hline & & & M. cordata & Leaves & [10] \\
\hline \multirow{3}{*}{48} & \multirow{3}{*}{$( \pm)$-Bocconarborine $\mathrm{A}$} & \multirow{3}{*}{$\mathrm{I}_{\mathrm{E}}$} & B. arborea & Aerial parts & [2] \\
\hline & & & M. cordata & Leaves & [10] \\
\hline & & & M. microcarpa & Whole plant & [21] \\
\hline \multirow{2}{*}{49} & \multirow{2}{*}{$( \pm)$-Bocconarborine B } & \multirow{2}{*}{$\mathrm{I}_{\mathrm{E}}$} & B. arborea & Aerial parts & [2] \\
\hline & & & M. cordata & Leaves & [10] \\
\hline 50 & 1, 3-Bis(11-hydrochelerythriny1)acetone & $\mathrm{I}_{\mathrm{E}}$ & B. arborea & - & {$[16]$} \\
\hline
\end{tabular}

I: benzophenanthridine $(\mathrm{BPA}) ; \mathrm{I}_{\mathrm{A}}$ : dihydrobenzophenanthridine; $\mathrm{I}_{\mathrm{B}}$ : QBPA; $\mathrm{I}_{\mathrm{C}}$ : $N$-demethylation BPA; $\mathrm{I}_{\mathrm{D}}$ : hexahydrobenzophenanthridine; $\mathrm{I}_{\mathrm{E}}$ : dimeric BPA; $\mathrm{I}_{\mathrm{F}}$ : seco-BPA. 
Table 2. Alkaloids isolated from Bocconieae.

\begin{tabular}{|c|c|c|c|c|c|}
\hline & Name & Type & Plant & Part & Ref. \\
\hline \multirow{3}{*}{51} & \multirow{3}{*}{ Berberine } & \multirow{3}{*}{ II } & B. frutescens & Roots, stalks, leaves & {$[30]$} \\
\hline & & & M. cordata & - & [10] \\
\hline & & & M. microcarpa & Roots & [31] \\
\hline 52 & Berberrabine & II & M. microcarpa & Whole plant & {$[21]$} \\
\hline \multirow{2}{*}{53} & \multirow{2}{*}{ Coptisine } & \multirow{2}{*}{ II } & B. frutescens & Roots, stalks and leaves & {$[30]$} \\
\hline & & & M. microcarpa & Roots & [31] \\
\hline 54 & Corysamine & II & B. frutescens & - & {$[37]$} \\
\hline 55 & Columbamine & II & B. frutescens & Roots, stalks, leaves & [30] \\
\hline 56 & Dehydrocorytenchine & II & M. cordata & Cultured cells & [39] \\
\hline 57 & Dehydrocheilanthifoline & II & M. cordata & - & {$[40]$} \\
\hline 58 & Tetrahydropalmatrubine & II & M. cordata & Cultured cells & [39] \\
\hline 59 & Corytenchine & II & M. cordata & Cultured cells & [39] \\
\hline 60 & (-)-Isocorypalmine & II & B. frutescens & Leaves, roots & {$[30,37,41]$} \\
\hline 61 & (-)-Scoulerine & II & B. frutescens & Roots, leaves & {$[30,37]$} \\
\hline 62 & (-)-cis-N-Methylcanadinium & II & B. frutescens & Roots & {$[37]$} \\
\hline 63 & $(-)-\alpha$-Canadine & II & B. frutescens & Roots, stalks, leaves & {$[30]$} \\
\hline 64 & Dehydrocicanthifoline & II & M. cordata & - & {$[40]$} \\
\hline 65 & $\beta$-Allocryptopine & III & M. microcarpa & Aerial parts, whole plant & {$[18,19,21]$} \\
\hline \multirow{4}{*}{66} & \multirow{4}{*}{$\alpha$-Allocryptopine } & \multirow{4}{*}{ III } & B. cordata & Leaves & {$[32]$} \\
\hline & & & M. cordata & Fruits & {$[10]$} \\
\hline & & & B. latisepala & Roots & [27] \\
\hline & & & M. microcarpa & Whole plant & [21] \\
\hline \multirow{5}{*}{67} & \multirow{5}{*}{ Protopine } & \multirow{5}{*}{ III } & B. latisepala & Leaves, roots & [27] \\
\hline & & & B. cordata & Leaves & [32] \\
\hline & & & B. frutescens & Roots, stalks, leaves & {$[30,41]$} \\
\hline & & & M. cordata & Cultured cells & [39] \\
\hline & & & M. microcarpa & Aerial parts, whole plant & {$[19,21]$} \\
\hline \multirow{2}{*}{68} & \multirow{2}{*}{ Cryptopine } & \multirow{2}{*}{ III } & M. cordata & Fruits & [10] \\
\hline & & & M. microcarpa & Aerial parts & [18] \\
\hline 69 & Protopine $N$-oxide & III & B. cordata & Whole plant & {$[10,42]$} \\
\hline 70 & Papaverine & IV & M. cordata & Cultured cells & [39] \\
\hline 71 & Laudanine & IV & M. cordata & Cultured cells & [43] \\
\hline 72 & Codamine & IV & M. cordata & Cultured cells & [43] \\
\hline 73 & Pseudocodamine & IV & M. cordata & Cultured cells & [43] \\
\hline 74 & Rhoeadine & IV & B. frutescens & Leaves, stalks & {$[30,41]$} \\
\hline 75 & $N$-p-Coumaroyltyramine & IV & M. microcarpa & Roots & [14] \\
\hline
\end{tabular}

II: protoberberine; III: protopine; IV: other types.

\section{Biological Activities}

Crude extracts, essential oils and other individual compounds from the plants of the tribe Bocconieae display insecticidal, cough treatment, antitumor and antifungal activities. Among all investigations, $M$. cordata is the most addressed species. 


\subsection{Cytotoxicity against Tumor Cells}

The in vitro anticancer properties of crude extract of $M$. cordata were assessed against MRC5 fetal lung fibroblasts and A549 adenocarcinomic epithelial cells. Viability of the treated MRC5 cells was reduced in a concentration-dependent manner, demonstrating that the normal lung cells are sensitive to the extract. Surprisingly, the A549 viability was slightly increased in response to extract exposure at a low concentration, whereas the viability was reduced accordingly at higher concentrations [44]. Fractions from the ethanol extract of the roots of $M$. microcarpa exhibited cytotoxicity against the Bel-7402, BGC-823, HCT-8, A2780 and A549 cell-lines, with $\mathrm{IC}_{50}$ values in the 1.1-23.8 $\mu \mathrm{g} / \mathrm{mL}$ range [14].

The total alkaloids of $M$. cordata showed in vivo inhibitory activity against transplanted tumors in mice in a dose-dependent manner [45], and further in vitro assessment of total alkaloids of $M$. cordata showed significantly inhibitory activity against the proliferation of human Hep3B cells and murine $\mathrm{H} 22$ cells, with $\mathrm{IC}_{50}$ values of $2.0-3.0 \mu \mathrm{g} / \mathrm{mL}$. The total alkaloids of $M$. cordata also inhibited the development of tumors and prolonged the survival of S180 tumor-bearing mice [46].

It was reported that chelerythrine (CHE, 21) inhibited the proliferation of BGC-823 human gastric cancer cells in a time- and dose-dependent manner, accompanied with $\mathrm{S}$ phase arrest. It also induced apoptosis by a mechanism involving a reduction in the mitochondrial membrane potential, the release of cytochrome c, activation of caspase 3 and cleavage of poly-ADP-ribose polymerase (PARP). In addition, CHE-induced apoptosis was accompanied by down-regulation of Bcl-xl and Bcl-2 proteins without change in the levels of Bax proteins [47]. Compounds 7, 12 and 34 displayed marked cytotoxicities against the Bel-7402, BGC-823, HCT-8, A2780 and A549 cell-lines, with $\mathrm{IC}_{50}$ values of 0.5-3.4 $\mu \mathrm{M}$, equal to the positive control camptothecin $(0.28$ to $3.15 \mu \mathrm{M})$ [14]. Adhami et al demonstrated that sanguinarine (SAN, 29) caused cell cycle blockade and apoptosis of human prostate carcinoma cells via modulation of cyclin kinase inhibitor-cyclin-cyclin-dependent kinase machinery [48]. Furthermore, SAN induced apoptosis of human pancreatic carcinoma AsPC-1 and BxPC-3 cells via modulations in Bcl-2 family proteins [49], and induced apoptosis in A549 human lung cancer cells primarily via cellular glutathione depletion [50].

Besides, protopine (PRO, 67), cryptopine (CRY, 68) and allocryptopine (ALL, 65/66) potently inhibited human cytochrome P450 (CYP) 2D6, with $\mathrm{IC}_{50}$ values lower than $1 \mu \mathrm{M}$. PRO and CRY moderately inhibited CYP2C19 with $\mathrm{IC}_{50}$ values of $1-10 \mu \mathrm{M}$ [51].

\subsection{Insecticidal Activities}

Ethanolic extract of the seeds of $M$. cordata showed a significant insecticidal effect against the growth of the cotton aphid Aphis gossypii Glover [26]. Crude extracts and fractions from the leaves of M. cordata were investigated in vitro against the fish parasite Ichthyophthirius multifiliis by a bioactivity-guided isolation method, and caresults showed that chloroform extract exhibited promising activity with $100 \%$ antiparasitic efficacy at the concentration of $70.0 \mathrm{mg} / \mathrm{L}$ after $4 \mathrm{~h}$ of exposure [52]. The chloroform extract of the leaves of $M$. microcarpa also showed a promising antiparasitic activity against I. multifiliis [22].

Compounds $\mathbf{4}$ and $\mathbf{1 0}$ showed potent activity against $I$. multifiliis with $\mathrm{EC}_{50}$ values of $9.43 \mathrm{mg} / \mathrm{L}$ and $5.18 \mathrm{mg} / \mathrm{L}$, respectively, after $48 \mathrm{~h}$ of exposure [22]. SAN (29) exhibited a remarkable inhibitory effect 
against I. multifiliis at a concentration of $0.7 \mathrm{mg} / \mathrm{L}$, with an $\mathrm{LC}_{50}$ value of $0.437 \mathrm{mg} / \mathrm{L}$ after $4 \mathrm{~h}$ of exposure. In vivo antiparasitic efficacy tests showed that the number of I. multifiliis on the gills in the treatment group (in $0.9 \mathrm{mg} / \mathrm{L} \mathrm{SAN}$ ) was reduced by $96.8 \%$ in comparison to the untreated at $25{ }^{\circ} \mathrm{C}$ for $48 \mathrm{~h}$. There were no deaths in the treatment group during the trial compared with a $40 \%$ death rate of the untreated fish [52]. Compound $\mathbf{1 0}$ showed significant inhibitory activity against Leishmania with an $\mathrm{IC}_{50}$ value of $0.014 \mu \mathrm{g} / \mathrm{mL}$, followed by compounds 4 and 11 with the same $\mathrm{IC}_{50}$ value of $0.166 \mu \mathrm{g} / \mathrm{mL}$ [24]. Compounds 6 and $\mathbf{1 3}$ demonstrated an effect in decreasing the survival rate of the cotton aphid by $76.1 \% \pm 7.9 \%$ and $73.6 \% \pm 14.6 \%$ at $100 \mathrm{ppm}$, respectively [26]. The bisulfates of CHE, SAN and total alkaloids from the fruits of $M$. cordata have molluscicidal activities against the snail Oncomlania hupensis, the intermediate host of schistosomiasis, in both time-and concentration-dependent manners, with $\mathrm{LC}_{50}$ values at $72 \mathrm{~h}$ of $2.05,0.19$, and $0.40 \mathrm{mg} / \mathrm{L}$, respectively [53].

Wang et al. reported that the extract of aerial parts of $M$. microcarpa and isolates $(\mathbf{2}, \mathbf{2 9}, \mathbf{6 5}, \mathbf{6 7}$, and 68), especially SAN (29), might be useful for the treatment of Dactylogyrus intermedius infections. Another in vivo anthelmintic assay backed the theory by reporting evident inhibitory effects with $\mathrm{EC}_{50}$ values of $0.37-8.13 \mathrm{mg} / \mathrm{L}[19]$.

\subsection{Antimicrobial Activity}

The plants of Bocconieae species, such as B. arborea [54] and B. frutescens [3], exhibited strong antimicrobial activity, therefore they have been applied extensively as traditional medicines for the treatment of diverse infectious diseases.

Methanolic extract of the leaves of $B$. arborea showed a general antimicrobial effect against Staphylococcus aureus, Escherichia coli, and Pseudomonas aeruginosa at $10 \mathrm{mg} / \mathrm{mL}$ and below [55]. Both ethanolic extract of leaves and hexane extract of stems of $B$. frutescens showed strong activities against $E$. coli and $S$. aureus [3]. Moreover, methanol and hexane extracts of $B$. frutescens leaves displayed in vitro antimycobacterial activity against Mycobacterium tuberculosis with the same MIC value of $125 \mu \mathrm{g} / \mathrm{mL}$ [56].

The bisulfates of quaternary benzophenanthridines from $M$. cordata showed strong inhibitory effects against Elsinoe ampelina, Colletotrichum gloeosporioides, Cercospora viticola, Pyricularia oryzae, Gibberella zeae, and Phytophythora capsici, with $\mathrm{EC}_{50}$ values of 3.35-10.08 $\mu \mathrm{g} / \mathrm{mL}$ [57]. Also, extracts from $M$. cordata formulated at $150 \mathrm{mg} / \mathrm{L}$ QBPA are used to spray greenhouse roses (Rosa sp.) infected by Sphaerotheca pannosa var. rosae (powdery mildew) at 10-day intervals. One day after application, symptoms of mildew infection show visible reduction by $60 \%$. Subsequent studies demonstrated that a tank of QBPAs provided enhanced control of powdery mildew on roses [58].

Methanolic extract of $B$. frutescens showed moderate inhibitory activity against Trichomonas vaginalis with annn $\mathrm{IC}_{50}$ value of $30.9 \mu \mathrm{g} / \mathrm{mL}$ [59]. Crude alcoholic extracts of different parts of fresh or dried B. frutescens possessed antimalarial activity. Compared to dried raw materials, extract of the fresh plant exhibited a higher inhibitory effect against Plasmodium berghei, especially of fresh green fruits $\left(\mathrm{IC}_{50} 2.4 \mu \mathrm{g} / \mathrm{mL}\right.$ ) [60]. QBPAs from the plants of the genus Macleaya are effective in the control of many fungal diseases. Methanolic extract of the leaves of B. arborea exhibited anti-yeast activity against Candida albicans with MIC value of $2.5 \mathrm{mg} / \mathrm{mL}$ [55]. 
Compounds $\mathbf{4}$ and $\mathbf{1 0}$ displayed significant antimicrobial activities against $S$. aureus, Streptococcus faecalis, Proteus mirabilis, and E. coli with MIC values of 9.3-300 $\mu \mathrm{g} / \mathrm{mL}$ [4]. Besides, they also exhibited the highest in vitro antifungal activity against Botrytis cinerea Pers with inhibitory rates of $98.32 \%$ and $95.16 \%$ at $50 \mu \mathrm{g} / \mathrm{mL}$, respectively, for they inhibit spore germination in a concentration-dependent manner. Moreover, they showed potent in vivo protective and curative effects on Erysiphe graminis and B. cinerea [61]. Compounds $\mathbf{2}$ and $\mathbf{1 4}$ both had the same MIC value of $12.5 \mu \mathrm{g} / \mathrm{mL}$ against a sensitive strain of M. tuberculosis H37Rv [25]. Compound 2 also exhibited activity against $S$. aureus and $S$. faecalis, with a MIC value around $25 \mu \mathrm{g} / \mathrm{mL}$ [2]. Further, 2, 4 and 10 exhibited anti-yeast activity against Candida albicans with MIC values of 12.0, 18.7 and $18.7 \mu \mathrm{g} / \mathrm{mL}$, respectively, while nystatin was $5.0 \mu \mathrm{g} / \mathrm{mL}[2,4]$.

CHE (21) and SAN (29) demonstrated a significant antifungal activity against Rhizoctonia solani with $\mathrm{IC}_{50}$ values of 0.55 and $0.47 \mu \mathrm{g} / \mathrm{mL}$, respectively. They are also effective against Botryosphaeria bernegeriana, Botrytis cinerea, Fusarium graminearum, F. oxysporum f.sp. lycopersici, F. oxysporum f.sp. vasinfectum, Magnaportheoryzae, and $R$. solani [62]. In most of the bacterial strains used, such as $S$. aureus CCM 3953, S. aureus CCM 4223, P. aeruginosa CCM 3955, two strains of E. coli (CCM 4225 and CCM 3954), and Streptococcus agalactiae, the antimicrobial activity increased as the concentration increased, which means the pure CHE and SAN exhibited the most potent effect. PRO (67) and ALL (65/66) showed weaker antimicrobial activity than CHE and SAN, and dihydrosanguinarine (10) had a mild inhibitory effect with MIC value around $500 \mu \mathrm{g} / \mathrm{mL}$, whereas 4 was inactive [10].

Besides, angoline (2), SAN, ALL, and CRY (68) also showed in vitro activities against fish pathogenic bacteria Aeromonas hydrophila, A. salmonicida, Vibrio anguillarum and $V$. harveyi with MIC values of 12.5-200 mg/L compared with florfenicol 0.5-2.0 mg/L [18].

\subsection{Anti-Inflammatory Property}

Some of the plants of this tribe have been shown to possess anti-inflammatory properties. The aqueous plant extract of $B$. arborea showed anti-inflammatory activity and is recommended for medical use in the treatment of oral inflammatory processes [38]. Extracts from $M$. cordata are also used in traditional medicine for their anti-inflammatory activity $[62,63]$.

Research on anti-inflammatory activity has been primarily focused on possible interactions with the nuclear factor- $\kappa \mathrm{B}(\mathrm{NF}-\kappa \mathrm{B})$ pathway which plays an important role in regulating the expression of cyclooxygenase-2 and pro-inflammatory cytokines. In cell models, SAN was found to inhibit NF- $\mathrm{B}$ activation and $\mathrm{CHE}$ suppressed inducible expression of cyclooxygenase-2. The anti-inflammatory action of CHE and SAN could also be associated with their ability to inhibit formation of superoxide radical by phagocyte NADPH oxidase. In contrast, the relevant molecular targets of PRO and ALL $\mathbf{( 6 5 / 6 6 )}$ have not been identified to date [64]. CHE and SAN exhibited local anti-inflammatory effects in the carrageenan-induced pawedema test in rats. SAN but not CHE inhibited the signal transduction pathways critical to the inflammatory response leading to NF- $\kappa B$ activation [63]. 


\subsection{Effect on Cardiovascular System}

The aqueous extract of $B$. frutescens possessed potent stimulatory effects with an $\mathrm{EC}_{50}$ of $18 \pm 2.4 \mu \mathrm{g} / \mathrm{mL}$, which presented maximum contractile response $\left(\mathrm{E}_{\max }=80.6 \pm 5.6 \%\right)$ when the vascular tone changed [65]. The methanolic and dichloromethane extracts of the roots of $B$. frutescens inhibited $\left[{ }^{3} \mathrm{H}\right]$-angiotensin II binding (AT II, $\mathrm{AT}_{1}$ receptor) by more than $50 \%$ [66].

$\mathrm{CHE}$ and SAN were significant inhibitors of $\left[{ }^{3} \mathrm{H}\right]-\mathrm{AT}$ II binding (hAT ${ }_{1}$ receptor) with $\mathrm{IC}_{50}$ values 9.93 and $1.90 \mu \mathrm{M}$, respectively. On the other side, the cyclo(-D-Trp-D-Asp-[prolyl-3, 4(n)-[ $\left.\left.{ }^{3} \mathrm{H}\right]\right]$ Pro-D-Val-Leu) binding $\left(\left[{ }^{3} \mathrm{H}\right]-\mathrm{BQ}-123, \mathrm{ET}_{\mathrm{A}}\right.$ receptor) was mildly inhibited [37].

SAN interacted with the human $\mathrm{AT}_{1}$ receptor in a slow, nearly irreversible and non-competitive manner. The inhibition of $\left[{ }^{3} \mathrm{H}\right]$ (2-ethoxy-1-[(2'-(1H-tetrazol-5-yl)biphenyl-4-yl)methyl]-1H-benzimidazoline-7-carboxylic acid) $\left(\left[{ }^{3} \mathrm{H}\right]\right.$ candesartan) binding by SAN was independent of cell viability, since the alkaloid inhibited both intact Chinese hamster ovary $(\mathrm{CHO})$ cells transfected with human $\mathrm{AT}_{1}$ receptor and with their cell membranes $\left(K_{\mathrm{i}}=0.14\right.$ and $1.10 \mu \mathrm{M}$, respectively) at a similar extent radioligand binding [67].

\subsection{Other Activities}

The aqueous extract of $B$. frutescens showed significant antisecretory activity with inhibitory rates of $86.0 \%$ at $300 \mathrm{mg} / \mathrm{kg}$ on cholera toxin-induced intestinal secretion in rat jejunal loops model [68]. $M$. cordata root powder could improve liver function in acute hepatic injuries. $M$. cordata could lessen the level of serum lactate dehydrogenase ( $\mathrm{LDH})$ and mortality rate of rats, while increasing the ratio of serum albumin/globulin (A/G), protecting cellular membrane effectively and inhibiting fibrosis in rats with chromic hepatic injury caused by tetrachloromethane. Furthermore, it enhanced the function of $\mathrm{T}$ and B lymphocytes [69]. The methanol extract of aerial parts of $M$. cordata exhibited strong antioxidative activity against total reactive oxygen species (ROS), with an $\mathrm{IC}_{50}$ value of $1.7 \mu \mathrm{g} / \mathrm{mL}$, compared to the positive control Trolox $(7.61 \pm 0.12 \mu \mathrm{g} / \mathrm{mL})$ [70]. The alkaloids from fruits of M. cordata collected in different regions possessed different antioxidant activities, with $\mathrm{IC}_{50}$ values ranging from 578 to $1,192 \mathrm{mg} / \mathrm{L}$ [71].

$\mathrm{CHE}$ and SAN, and their mixture (sanguiritrin) from $M$. cordata were inhibitors of aminopeptidase A and dipeptidyl peptidase IV. They inhibited amino peptidase $\mathrm{N}$ by $82 \%, 82 \%$, and $88 \%$, DPP IV by $38 \%, 62 \%$, and $57 \%$, respectively, at $50 \mathrm{mM}$. When bovine serum albumin $(500 \mu \mathrm{g} / \mathrm{mL})$ was added, the inhibition of both proteases by QBPA at $50 \mu \mathrm{M}$ was significantly diminished, which suggested that strong interaction of $\mathrm{CHE}$ and SAN with bovine and human serum albumin was proved by electrophoretic determination of their respective conditional binding constants [72]. CHE, SAN and QBPA extract from $M$. cordata exerted differential inhibitory effects against hydrolytic activity of particular dipeptidyl peptidase (DPP)-like enzyme isolated from human blood plasma and from human and rat glioma cell lines. The low-MW form of DPP-IV-like enzyme activity, corresponding most probably with DPP-8, observed only in glioma cells but not in human plasma, was inhibited preferentially by CHE, SAN and the QBPA extract, indicating that some QBPA's biological effects could be determined by tissue and cell type specific dipeptidyl peptidase IV-like molecules expression 
pattern [73]. SAN may, under appropriate conditions, increase the capacity of the enzymatic antioxidant defense system via activation of the p38 MAPK/Nrf2 pathway [64].

The alkaloids of $M$. cordata are the major active ingredients in Sangrovit, a phytogenic feed additive composed mainly of CHE and SAN. Jankowski et al. found that feeding broilers with $20 \mathrm{mg} / \mathrm{kg}$ of Sangrovit led to a significant increase of mucosal maltase, reduced duodenal villus height yet no change in $\mathrm{pH}$ in the small and lower intestine [74]. Despite lacking of improvement in final body weight, a low dose of dietary Sangrovit was found to exert positive effects on caecal metabolism of broilers [75]. In addition, macarpine (31), a QBPA described only in two species, was recently reported as promising fluorescent probe for labeling of cell nuclei at fluorescence microscopy and flow cytometry [31].

\section{Toxicity and Side Effects}

Modern pharmacological studies show that the QBPA bisulfates from M. cordata exhibited low toxicity in acute oral, acute inhalation and acute dermal toxicity tests, and no stimulating effect on the skin, but weak sensitization and severe irritation to the eyes [57]. It was reported in China that one person who ate bee slag containing $M$. cordata appeared to show symptoms like dizziness, tinnitus, numbness, and nausea [76]. There was another report that one female died after taking about $250 \mathrm{~mL}$ of fresh root decoction (125 g/250 mL) of $M$. cordata, supposedly used for curing joint pain [77].

The subchronic safety of sanguiritrin was assessed by feeding rats a diet containing $120 \mathrm{ppm}$ (100 ppm QBPA) for 109 days, but no adverse effects were observed on rat organism, including no influence on the gut mucosal epithelium, liver tissue and any biochemical parameters. Oxidative stress did not manifest during the experiment [78]. The sensory evaluation of broiler breast and thigh meat did not reveal any negative influence of dietary supplementation with a $30 \mathrm{mg} / \mathrm{kg}$ dose of the alkaloid-containing preparation Sangrovitin for 5 week [79]. Rawling, et al. reported that low levels of Sangrovit $(25-100 \mathrm{mg} / \mathrm{kg}$ ) had a positive effect on tilapia growth performance with no apparent effects on carcass composition, hepatic function or health status [80]. Besides, the effects of daily administration of the extract from $M$. cordata ( 2 and $100 \mathrm{mg} / \mathrm{kg}$ feed, SAN:CHE = 3:1) in the diet on the health status of swine were evaluated, and the results showed that an average daily oral dose of alkaloids up to $5 \mathrm{mg} / \mathrm{kg}$ animal body weight proved to be safe [81]. The cytotoxicity analysis on primary cultures of human hepatocytes suggested that $\mathrm{CHE}$ and dihydrochelerythrine (4) were nontoxic up to $50 \mu \mathrm{M}$ concentration [82]. However, the aqueous extracts of the dry roots of M. microcarpa showed toxic effect against growth of cultured algae (P. subcapitata and S. quadricauda) and cyanobacteria (M. aeruginosa and $S$. leopoliensis), with EC $_{50}$ values of 626.90-984.81 mg/L [83].

SAN had been reported to form DNA adducts in vitro and to increase the levels of DNA single strand cleavage in the blood and bone marrow of mice injected intraperitoneally. There was no genotoxic effects of orally administrated $120 \mathrm{mg} / \mathrm{kg}$ feed Sangrovit in pigs or rats in a 90-day observation. M. cordata extract and/or Sangrovit induced no DNA damage to rat lymphocytes or hepatocytes after 90-days oral administration [84]. Some parameters of dextran sulfate sodium (DSS)-induced colitis were improved by adding $500 \mathrm{ppm}$ Sangrovit to feed the rats. For example, it showed less severe damage to the colon mucosa and decreased histological colitis scores. What's more, it showed a diminished expression of DSS-induced COX-2, significantly mitigating myeloperoxidase activity in colon tissue and reducing level of glutathione in erythrocytes [63]. 
Broadly, the Bocconieae alkaloids are considerable toxic to some extent, and for application of the extracts and pure alkaloids from the tribe attention must be paid to their side effects.

\section{Discussion and Conclusions}

A total of 75 alkaloids were described from the plants of the tribe Bocconieae so far, including benzophenanthridines, protoberberines, protopines, and others. Some exhibited such a variety of biological effects such as antitumor, insecticidal, and antimicrobial activities. SAN (29) has shown a promising future as a lead compound for the development of biological pesticides. Meanwhile, the side effects of the plants of this tribe should also be given adequate attention.

Currently, there are two opposing opinions when it comes to the classification system: one suggests that Macleaya and Bocconia should be classified as the tribe Bocconieae, which is documented in the Hutchinson System, while the other insists that Macleaya and Bocconia should be placed in Chelidonieae, because of the characteristic alkaloids, especially CHE and SAN, generally occurred in the Chelidonieae. Our present review reveals that there is no obvious difference in alkaloids observed in these two genera compared with those from Chelidonieae, and therefore provides chemotaxonomic evidence supporting the latter classification, although more substantial evidence is needed to determine the final taxonomy of these genera.

Since the plants of the tribe Bocconieae have ecological adaptability advantages, and are easy to cultivate and manage, their exploitation and utilization as natural antimicrobials have attracted much attention around the world. For instance, the alkaloids from M. cordata were used by United States as breath freshener and air freshener [85].

Overall, as an alkaloid-rich source, further in-depth research on the plants of the tribe Bocconieae, regarding their phytochemical investigation, determination of stereochemistry, in vivo and in vitro biological evaluation, and economic exploration, are of great significance and positively called for.

\section{Acknowledgments}

The authors would like to thank Miss Ding W.J. (Beijing University of Chinese Medicine) who thoroughly polished the English in the article for us.

\section{Author Contributions}

Xuelong Yu and Xiaoli Gao drafted and revised the manuscript, Zhixiang Zhu, Yuan Cao and Qian Zhang made suggestions and played an important role in preparing this paper, and Xingyun Chai and Pengfei Tu approved the final version.

\section{Conflicts of Interest}

The authors declare no conflict of interest.

\section{References}

1. Institute of Botany, the Chinese Academy of Sciences. Iconographia Cormophytorum Sinicorum; Science Press: Beijing, China, 1994; Volume 2, p. 4. 
2. Julian, A.; Delgado, G. ( \pm )-Bocconarborines A and B, novel 1, 3-bis-benzo[c]phenanthridinyl acetone alkaloids from Bocconia arborea. Rev. Soc. Quim. Mex. 2001, 45, 189-194.

3. Sanchez-Arreola, E.; Hernandez-Molina, L.R.; Sanchez-Salas, J.L.; Martinez-Espino, G. Alkaloids from Bocconia frutescens and biological activity of their extracts. Pharm. Biol. 2006, $44,540-543$.

4. Navarro, V.; Delgado, G. Two antimicrobial alkaloids from Bocconia arborea. J. Ethnopharmacol. 1999, 66, 223-226.

5. Pi, G.P.; Ren, P.; Yu, J.M.; Shi, R.F.; Yuan, Z.; Wang, C.H. Separation of sanguinarine and chelerythrine in Macleaya cordata (Willd) R. Br. based on methyl acrylate-co-divinylbenzene macroporous adsorbents. J. Chromatogr. A 2008, 1192, 17-24.

6. Guo, Z.Q.; Guo, Q.; Zhang, S.Y.; Li, C.; Chai, X.Y.; Tu, P.F. Chemical constituents from the aerial parts of Meconopsis horridula (Papaveraceae). Biochem. Syst. Ecol. 2014, 55, 329-332.

7. Slaninova, I.; Pencikova, K.; Urbanova, J.; Slanina, J.; Taborska E. Antitumour activities of sanguinarine and related alkaloids. Phytochem. Rev. 2014, 13, 51-68.

8. Su, Z.W. The chemotaxonomy of angiosperms families (V): Papaveraceae. J. Int. Pharm. Res. 1981, 2, 65-70.

9. Zhang, G.L.; Ruecker, G.; Breitmaier, E.; Nieger, M.; Mayer, R.; Steinbeck, C. Alkaloids from Dactylicapnos torulosa. Phytochemistry 1995, 40, 299-305.

10. Kosina, P.; Gregorova, J.; Gruz, J.; Vacek, J.; Kolar, M.; Vogel, M.; Roos, W.; Naumann, K.; Simanek, V.; Ulrichova, J. Phytochemical and antimicrobial characterization of Macleaya cordata herb. Fitoterapia 2010, 81, 1006-1012.

11. Chen, L.J.; Zhou, S.Y.; Shi, H.Z.; Yin, J. Determination of Chemical Composition of the Essential Oil from Macleaya cordata by GC-MS. Chin. Agric. Sci. Bull. 2009, 25, 94-96.

12. Xiao, H.J. Study on the Chemical Constituents and their Bioactivities from Macleaya cordata. Master Thesis, Tianjin Medical University, Tianjin, China, 2013.

13. Chavez, M.I.; Julian, A.; Delgado, G. Structure elucidation and ${ }^{13} \mathrm{C}-\mathrm{NMR}$ spectral assignments of $3 \alpha$-hydroxyolean-12-en-30-oic acid, a new triterpene from Bocconia arborea. Magn. Reson. Chem. 2003, 41, 143-144.

14. Deng, A.J.; Qin, H.L. Cytotoxic dihydrobenzophenanthridine alkaloids from the roots of Macleaya microcarpa. Phytochemistry 2010, 71, 816-822.

15. Martinez-Martinez, F.J.; Padilla-Martinez, I.I.; Hernandez-Carlos, B.; Perez-Gutierrez, R.M.; Garcia-Baez, E.V. X-ray diffraction and total ${ }^{1} \mathrm{H}$ and ${ }^{13} \mathrm{C}$ NMR assignment of $(R S)$-5,6-dihydro-7, 8-dimethoxy-5-methyl-6-(2-oxopropyl)-(2,3-methylenedioxyphenyl)-[c]-phenanthridine ((RS)-6acetonyldihydrochelerythrine). J. Chem. Crystallogr. 2002, 32, 63-68.

16. MacLean, D.B.; Gracey, D.E.F.; Saunders, J.K.; Rodrigo, R.; Manske, R.H.F. Benzophenanthridine alkaloids from Bocconia arborea. Can. J. Chem. 1969, 47, 1951-1956.

17. Lee, S.K.; Qing, W.G.; Mar, W.; Luyengi, L.; Mehta, R.G.; Kawanishi, K.; Fong, H.H.S.; Beecher, C.W.W.; Kinghorn, A.D.; Pezzuto, J.M. Angoline and chelerythrine, benzophenanthridine alkaloids that do not inhibit protein kinase C. J. Biol. Chem. 1998, 273, 19829-19833.

18. Kang, Y.J.; Yi, Y.L.; Zhang, C.; Wu, S.Q.; Shi, C.B.; Wang, G.X. Bioassay-guided isolation and identification of active compounds from Macleaya microcarpa (Maxim) Fedde against fish pathogenics bacteria. Aquac. Res. 2013, 44, 1221-1228. 
19. Wang, G.X.; Zhou, Z.; Jiang, D.X.; Han, J.; Wang, J.F.; Zhao, L.W.; Li, J. In vivo anthelmintic activity of five alkaloids from Macleaya microcarpa (Maxim) Fedde against Dactylogyrus intermedius in Carassius auratus. Vet. Parasitol. 2010, 171, 305-313.

20. Oechslin, S.M.; Koenig, G.M.; Oechslin-Merkel, K.; Wright, A.D.; Kinghorn, A.D.; Sticher, O.; Miyagawa, M. An NMR study of four benzophenanthridine alkaloids. J. Nat. Prod. 1991, 54, 519-524.

21. Yang, X.J.; Miao, F.; Zheng, F.; Zhou, L.; Wang, X.; Geng, H.L.; Sun, W. Isolation and identification of alkaloids from Macleaya microcarpa (Maxim.) Fedde. Acta Bot. Boreal-Occident. Sin. 2010, 30, 405-411.

22. Yao, J.Y.; Zhou, Z.M.; Li, X.L.; Yin, W.L.; Ru, H.S.; Pan, X.Y.; Hao, G.J.; Xu, Y.; Shen, J.Y. Antiparasitic efficacy of dihydrosanguinarine and dihydrochelerythrine from Macleaya microcarpa against Ichthyophthirius multifiliis in richadsin (Squaliobarbus. curriculus). Vet. Parasitol. 2011, 183, 8-13.

23. Feng, F.; Ye, F.Z.; Li, C.L.; Liu, W.Y.; Xie, N. New benzophenanthridine isoquinoline alkaloids from Macleaya cordata. Chin. J. Nat. Med. 2012, 10, 378-382.

24. Fuchino, H.; Kawano, M.; Mori-Yasumoto, K.; Sekita, S.; Satake, M.; Ishikawa, T.; Kiuchi, F.; Kawahara, N. In vitro leishmanicidal activity of benzophenanthridine alkaloids from Bocconia pearcei and related compounds. Chem. Pharm. Bull. 2010, 58, 1047-1050.

25. Rayo Camacho-Corona, M.; Jesus Favela-Hernandez, J.M.; Gonzalez-Santiago, O.; GarzaGonzalez, E.; Molina-Salinas, G.M.; Said-Fernandez, S.; Delgado, G.; Luna-Herrera, J. Evaluation of some plant-derived secondary metabolites against sensitive and multidrug-resistant Mycobacterium tuberculosis. J. Mex. Chem. Soc. 2009, 53, 71-75.

26. Baek, M.Y.; Park, H.J.; Kim, G.M.; Lee, D.Y.; Lee, G.Y.; Moon, S.J.; Ahn, E.M.; Kim, G.S.; Bang, M.H.; Baek, N.I. Insecticidal alkaloids from the seeds of Macleaya cordata on cotton aphid (Aphis gossypii). J. Korean Soc. Appl. Biol. Chem. 2013, 56, 135-140.

27. Dominguez, X.A.; Delgado, J.G.; Monroy C., A.; Armendariz, L.G.; Alcala, A.; Quevedo, J.; Rojas, P. A chemical study of Bocconia latisepala Wat. Can. J. Chem. 1965, 43, 679-682.

28. Ishii, H.; Hosoya, K.; Takao, N. Bocconoline: A new type dihydrobenzo[c]phenanthridine alkaloid possessing a unique substituent at $\mathrm{C}_{6}$ position. Tetrahedron Lett. 1971, 12, 2429-2432.

29. Tolkachev, O.N.; Savina, A.A.; Sheichenko, V.I.; Proskudina, V.V. 8-O-demethylchelerythrine from Macleaya cordata. Pharm. Chem. J. 1999, 33, 86-87.

30. Taborska, E.; Veznik, F.; Slavik, J. Alkaloids of the Papaveraceae. LXXI. Alkaloids from Bocconia frutescens L. Collect. Czech. Chem. Commun. 1980, 45, 1301-1304.

31. Pěnčíková, K.; Urbanová, J.; Musil, P.; Táborská, E.; Gregorová, J. Seasonal variation of bioactive alkaloid contents in Macleaya microcarpa (Maxim.) Fedde. Molecules 2011, 16, 3391-3401.

32. Kiryakov, N.G.; Kitova, M.S.; Georgieva, A.V. Alkaloids of Bocconi acordata. Cr. Acad. Bulg. Sci. 1967, 20, 189-192.

33. Luo, X.B.; Chen, B.; Yao, S.Z. Rapid determination of protopine, allocryptopine, sanguinarine and chelerythrine in fruits of Macleaya cordata by microwave-assisted solvent extraction and HPLC-ESI/MS. Phytochem. Anal. 2006, 17, 431-438.

34. Onda, M.; Abe, K.; Yonezawa, K.; Esumi, N.; Suzuki, T. Constituents of Bocconia cordata. II. Bocconine. Chem. Pharm. Bull. 1970, 18, 1435-1439. 
35. Konda, Y.; Harigaya, Y.; Onda, M. Studies on the constituents of Bocconia cordata. III. Structure elucidation of bocconine by means of nuclear magnetic resonance spectroscopic studies. J. Heterocycl. Chem. 1986, 23, 877-879.

36. Takao, N.; Kamigauchi, M.; Okada, M. Biosynthesis of benzo[c]phenanthridine alkaloids sanguinarine, chelirubine and macarpine. Helv. Chim. Acta 1983, 66, 473-484.

37. Caballero-George, C.; Vanderheyden, P.M.L.; Apers, S.; van den Heuvel, H.; Solis, P.N.; Gupta, M.P.; Claeys, M.; Pieters, L.; Vauquelin, G.; Vlietinck, A.J. Inhibitory activity on binding of specific ligands to the human angiotensin II $\mathrm{AT}_{1}$ and endothelin $1 \mathrm{ET}_{\mathrm{A}}$ receptors: Bioactive benzo[c]phenanthridine alkaloids from the root of Bocconia frutescents. Planta Med. 2002, 68, 770-775.

38. Gutierrez, R.M.; Vargas Solis, R.; Diaz Gutierrez, G.; Martinez-Martinez, F.J. Identification of benzophenanthridine alkaloids from Bocconia arborea by gas chromatography-mass spectrometry. Phytochem. Anal. 2002, 13, 177-180.

39. Iwasa, K.; Cui, W.; Sugiura, M.; Takeuchi, A.; Moriyasu, M.; Takeda, K. Structural analyses of metabolites of phenolic 1-benzyltetrahydroisoquinolines in plant cell cultures by LC/NMR, LC/MS, and LC/CD. J. Nat. Prod. 2005, 68, 992-1000.

40. Wu, M.L.; Zhang, D.Z.; Xu, Q.J.; Xie, R.R.; Li, Q.Q. Advance in studies on Macleaya cordata. Asia-Pac. Tradit. Med. 2009, 5, 144-145.

41. Slavik, J.; Slavikova, L. Alkaloids of Papaveraceae. LIX. Alkaloids from the leaves of Bocconia frutescens L. Collect. Czech. Chem. Commun. 1975, 40, 3206-3210.

42. Iwasa, K.; Okada, M.; Takao, N. Protopine-N.-oxide, an alkaloid from Bocconia cordata. Phytochemistry 1983, 22, 627-628.

43. Iwasa, K.; Doi, Y.; Takahashi, T.; Cui, W.; Nishiyama, Y.; Tode, C.; Moriyasu, M.; Takeda, K.; Minami, H.; Ikezawa, N.; et al. Enantiomeric separation of racemic 1-benzyl- $N$-methyltetrahydroisoquinolines on chiral columns and chiral purity determinations of the $O$-methylated metabolites in plant cell cultures by HPLC-CD on-line coupling in combination with HPLC-MS. Phytochemistry 2009, 70, 198-206.

44. Liu, M.; Lin, Y.L.; Chen, X.R.; Liao, C.C.; Poo, W.K. In vitro assessment of Macleaya cordata crude extract bioactivity and anticancer properties in normal and cancerous human lung cells. Exp. Toxicol. Pathol. 2013, 65, 775-787.

45. Fan, S.L.; Jiao, F.; Zhang, Y.; An, C.X.; Fu, J.M. Study on the effects of total alkaloids from Macleaya cordata on transplantable animal tumors. Shanxi Oncol. Med. 2000, 8, 174-149.

46. Pang, J.X.; Ma, R.Q.; Liu, L.M.; Jiang, Y.P.; Sun, L.S. Total alkaloid of Macleaya cordata: In vitro cytotoxic effect on Hep3B cells and in vivo antitumor effect in mice. J. First Mil. Med. Univ. 2005, 25, 325-328.

47. Zhang, Z.F.; Guo, Y.; Zhang, L.W.; Zhang, J.B.; Wei, X.H. Chelerythrine chloride from Macleaya cordata induces growth inhibition and apoptosis in human gastric cancer BGC-823 cells. Acta Pharm. Sin. B 2012, 2, 464-471.

48. Adhami, V.M.; Aziz, M.H.; Reagan-Shaw, S.R.; Nihal, M.; Mukhtar, H.; Ahmad, N. Sanguinarine causes cell cycle blockade and apoptosis of human prostate carcinoma cells via modulation of cyclin kinase inhibitor-cyclin-cyclin-dependent kinase machinery. Mol. Cancer Ther. 2004, 3, 933-940. 
49. Ahsan, H.; Reagan-Shaw, S.; Breur, J.; Ahmad, N. Sanguinarine induces apoptosis of human pancreatic carcinoma AsPC-1 and BxPC-3 cells via modulations in Bcl-2 family proteins. Cancer Lett. 2007, 249, 198-208.

50. Jang, B.C.; Park, J.G.; Song, D.K.; Baek, W.K.; Yoo, S.K.; Jung, K.H.; Park, G.Y.; Lee, T.Y.; Suh, S.L. Sanguinarine induces apoptosis in A549 human lung cancer cells primarily via cellular glutathione depletion. Toxicol. In Vitro 2009, 23, 281-287.

51. Salminen, K.A.; Meyer, A.; Jerabkova, L.; Korhonen, L.E.; Rahnasto, M.; Juvonen, R.O.; Imming, P.; Raunio, H. Inhibition of human drug metabolizing cytochrome P450 enzymes by plant isoquinoline alkaloids. Phytomedicine 2011, 18, 533-538.

52. Yao, J.Y.; Shen, J.Y.; Li, X.L.; Xu, Y.; Hao, G.J.; Pan, X.Y.; Wang, G.X.; Yin, W.L. Effect of sanguinarine from the leaves of Macleaya cordata against Ichthyophthirius multifiliis in grass carp (Ctenopharyngodon idella). Parasitol. Res. 2010, 107, 1035-1042.

53. Zhong, M.; Li, G.Y.; Zeng, J.G.; Zhang, L.; Huang, K.L.; She, J.M.; Li, X.; Wei, W.Y. Evaluation of molluscicidal activities of benzo[c]phenanthridine alkaloids from Macleaya cordata (Wild) R. Br. on snail hosts of Schistosoma japonicum. J. Med. Plant. Res. 2011, 5, 521-526.

54. Navarro, V.; Rojas, G.; Delgado, G.; Lozoya, X. Antimicrobial compounds detected in Bocconia arborea extracts by a direct bioautographic method. Arch. Med. Res. 1998, 29, 191-194.

55. Navarro V.; Villarreal M.L.; Rojas G.; Lozoya X. Antimicrobial evaluation of some plants used in Mexican traditional medicine for the treatment of infectious diseases. J. Ethnopharmacol. 1996, 53, 143-147.

56. Cruz-Vega, D.E.; Verde-Star, M.J.; Salinas-Gonzalez, N.; Rosales-Hernandez, B.; Estrada-Garcia, I.; Mendez-Aragon, P.; Carranza-Rosales, P.; Gonzalez-Garza, M.T.; Castro-Garza, J. Antimycobacterial activity of Juglans regia, Juglans mollis, Carya illinoensis and Bocconia frutescens. Phytother. Res. 2008, 22, 557-559.

57. Wang, B.; Cheng, P.; Chen, J.L.; Zeng, J.G. Extraction of quaternary benzophenanthridine alkaloids (QBAs) from Macleaya cordata and antibacterial activity, acute toxicity of the QBAs bisulfate. Chin. J. Pestic. Sci. 2013, 15, 299-304.

58. Newman, S.E.; Roll, M.J.; Harkrader, R.J. A naturally occurring compound for controlling powdery mildew of greenhouse roses. Hortscience 1999, 34, 686-689.

59. Calzada, F.; Yepez-Mulia, L.; Tapia-Contreras, A. Effect of Mexican medicinal plant used to treat trichomoniasis on Trichomonas vaginalis trophozoites. J. Ethnopharmacol. 2007, 113, 248-251.

60. Chinchilla, M.; Valerio, I.; Sanchez, R.; Mora, V.; Bagnarello, V.; Martinez, L.; Gonzalez, A.; Vanegas, J.C.; Apestegui, A. In vitro antimalarial activity of extracts of some plants from a biological reserve in Costa Rica. Rev. Biol. Trop. 2012, 60, 881-891.

61. Feng, G.; Zhang, J.; Liu, Y.Q. Inhibitory activity of dihydrosanguinarine and dihydrochelerythrine against phytopathogenic fungi. Nat. Prod. Res. 2011, 25, 1082-1089.

62. Liu, H.; Wang, J.H.; Zhao, J.L.; Lu, S.Q.; Wang, J.G.; Jiang, W.B.; Ma, Z.H.; Zhou, L.G. Isoquinoline alkaloids from Macleaya cordata active against plant microbial pathogens. Nat. Prod. Commun. 2009, 4, 1557-1560.

63. Vrublova, E.; Vostalova, J.; Ehrmann, J.; Palikova, I.; Vrbkova, J.; Vacek, J.; Cibicek, N.; Vecera, R.; Ulrichova, J.; Simanek, V. The phytogenetic feed additive Sangrovit modulates dextran sulfate sodium-induced colitis in rats. Vet. Med.-Czech. 2010, 55, 610-618. 
64. Vrba, J.; Orolinova, E.; Ulrichova, J. Induction of heme oxygenase-1 by Macleaya cordata extract and its constituent sanguinarine in RAW264.7 cells. Fitoterapia 2012, 83, 329-335.

65. Ibarra-Alvarado, C.; Rojas, A.; Mendoza, S.; Bah, M.; Gutierrez, D.M.; Hernandez-Sandoval, L.; Martinez, M. Vasoactive and antioxidant activities of plants used in Mexican traditional medicine for the treatment of cardiovascular diseases. Pharm. Biol. 2010, 48, 732-739.

66. Caballero-George, C.; Vanderheyden, P.M.L.; Solis, P.N.; Pieters L.; Shahat, A.A.; Gupta, M.P.; Vauquelin, G.; Vlietinck, A.J. Biological screening of selected medicinal Panamanian plants by radioligand-binding techniques. Phytomedicine 2001, 8, 59-70.

67. Caballero-George, C.; Vanderheyden, P.M.L.; Solis, P.N.; Gupta, M.P.; Pieters, L.; Vauquelin, G.; Vlietinck, A. In vitro effect of sanguinarine alkaloid on binding of $\left[{ }^{3} \mathrm{H}\right]$ candesartan to the human angiotensin $\mathrm{AT}_{1}$ receptor. Eur. J. Pharmacol. 2003, 458, 257-262.

68. Velazquez, C.; Calzada, F.; Torres, J.; Gonzalez, F.; Ceballos, G. Antisecretory activity of plants used to treat gastrointestinal disorders in Mexico. J. Ethnopharmacol. 2006, 103, 66-70.

69. Yang, J.; Wang, J.; Liu, X.S.; Fang, X.M. Experimental studies on pharmacodynamic effect of Macleaya cordata. Chin. Med. Mat. 1999, 22, 82-85.

70. Kang, H.S.; Chung, H.Y.; Son, K.H.; Kang, S.S.; Choi, J.S. Scavenging effect of Korean medicinal plants on the peroxynitrite and total ROS. Nat. Prod. Sci. 2003, 9, 73-79.

71. Zhong, M.; Huang, K.L.; Zeng, J.G.; Li, S.; Zhang, L. Determination of contents of eight alkaloids in fruits of Macleaya cordata (Willd) $\mathrm{R}$. Br. from different habitats and antioxidant activities of extracts. J. Cent. South Univ. Technol. 2010, 17, 472-479.

72. Sedo, A.; Vlasicova, K.; Bartak, P.; Vespalec, R.; Vicar, J.; Simanek, V.; Ulrichova, J. Quaternary benzo[c]phenanthridine alkaloids as inhibitors of aminopeptidase $\mathrm{N}$ and dipeptidyl peptidase IV. Phytother. Res. 2002, 16, 84-87.

73. Sedo, A.; Malik, R.; Vicar, J.; Simanek, V.; Ulrichova, J. Quaternary benzo[c]phenanthridine alkaloids as inhibitors of dipeptidyl peptidase IV-like activity bearing enzymes in human blood plasma and glioma cell lines. Physiol. Res. 2003, 52, 367-372.

74. Jankowski, J.; Zdunczyk, Z.; Juskiewicz, J.; Kozlowski, K.; Lecewicz, A.; Jeroch, H. Gastrointestinal tract and metabolic response of broilers to diets with the Macleaya cordata alkaloid extract. Arch. Geflugelk. 2009, 73, 95-101.

75. Juskiewicz, J.; Gruzauskas, R.; Zdunczyk, Z.; Semaskaite, A.; Jankowski, J.; Totilas, Z.; Jarule, V.; Sasyte, V.; Zdunczyk, P.; Raceviciute-Stupeliene, A.; et al. Effects of dietary addition of Macleaya cordata alkaloid extract on growth performance, caecal indices and breast meat fatty acids profile in male broilers. J. Anim. Physiol. Anim. Nutr. 2011, 95, 171-178.

76. Shu, K.G. A report of poisoning by food containing Macleaya cordata. Chin. J. Med. 1980, 11, $23-23$.

77. Chen, J.K. Report of a case: Poisoning by Macleaya cordata. Hunan Med. J. 1991, 8, 159.

78. Psotova, J.; Vecera, R.; Zdarilova, A.; Anzenbacherova, E.; Kosina, P.; Svobodova, A.; Hrbac, J.; Jirovsky, D.; Stiborova, M.; Lichnovsky, V.; et al. Safety assessment of sanguiritrin, alkaloid fraction of Macleaya cordata, in rats. Vet. Med.-Czech. 2006, 51, 145-155. 
79. Zdunczyk, Z.; Gruzauskas, R.; Juskiewicz, J.; Semaskaite, A.; Jankowski, J.; Godycka-Klos, I.; Jarule, V.; Miezeliene, A.; Alencikiene, G. Growth performance, gastrointestinal tract responses, and meat characteristics of broiler chickens fed a diet containing the natural alkaloid sanguinarine from Macleaya cordata. J. Appl. Poult. Res. 2010, 19, 393-400.

80. Rawling, M.D.; Merrifield, D.L.; Davies, S.J. Preliminary assessment of dietary supplementation of Sangrovit on red tilapia (Oreochromis niloticus) growth performance and health. Aquaculture 2009, 294, 118-122.

81. Kosina, P.; Walterova, D.; Ulrichova, J., Lichnovsky, V.; Stiborova, M.; Rydlova, H.; Vicar, J.; Krecman, V.; Brabec, M.J.; Simanek, V. Sanguinarine and chelerythrine: assessment of safety on pigs in ninety days feeding experiment. Food Chem. Toxicol. 2004, 42, 85-91.

82. Vacek, J.; Papoušková, B.; Kosina, P.; Galandáková, A.; Ulrichová, J. Mass spectrometric investigation of chelerythrine and dihydrochelerythrine biotransformation patterns in human hepatocytes. J. Chromatogr. B 2013, 941, 17-24.

83. Jancula, D.; Suchomelova, J.; Gregor, J.; Smutna, M.; Marsalek, B.; Taborska, E. Effects of aqueous extracts from five species of the family Papaveraceae on selected aquatic organisms. Environ. Toxicol. 2007, 22, 480-486.

84. Stiborova, M.; Vostalova, J.; Zdarilova, A.; Ulrichova, J.; Hudecek, J.; Tschirner, K.; Simanek, V. Macleaya cordata extract and Sangrovit genotoxicity. Assessment in vivo. Biomed. Pap. 2008, 152, 35-39.

85. Archambault, J.; Williams, R.D.; Bedard, C.; Chavarie, C. Production of sanguinarine by elicited plant cell culture. I. Shake flask suspension cultures. J. Biotechnol. 1996, 46, 95-105.

(C) 2014 by the authors; licensee MDPI, Basel, Switzerland. This article is an open access article distributed under the terms and conditions of the Creative Commons Attribution license (http://creativecommons.org/licenses/by/3.0/). 